NBER WORKING PAPER SERIES

\title{
SARGENT-WALLACE MEETS KRUGMAN-FLOOD-GARBER, OR: WHY SOVEREIGN DEBT SWAPS DON'T AVERT MACROECONOMIC CRISES
}

\author{
Joshua Aizenman \\ Kenneth M. Kletzer \\ Brian Pinto \\ Working Paper 9190 \\ http://www.nber.org/papers/w9190
NATIONAL BUREAU OF ECONOMIC RESEARCH
1050 Massachusetts Avenue
Cambridge, MA 02138
September 2002

\begin{abstract}
We are indebted to Robert Flood for the first line of this title. Joshua Aizenman and Kenneth Kletzer are Professors of Economics at the University of California, Santa Cruz. Brian Pinto is at the World Bank. This paper has been written as an input into a book on "Managing Volatility" currently under preparation at the Bank. The authors acknowledge helpful comments from Zia Qureshi. The views expressed herein are entirely those of the authors and do not necessarily represent the views of the World Bank, its Executive Directors or the countries they represent.

(C) 2002 by Joshua Aizenman, Kenneth M. Kletzer and Brian Pinto. All rights reserved. Short sections of text, not to exceed two paragraphs, may be quoted without explicit permission provided that full credit, including (C) notice, is given to the source.
\end{abstract}


Sargent-Wallace Meets Krugman-Flood-Garber, or: Why Sovereign Debt Swaps

Don't Avert Macroeconomic Crises

Joshua Aizenman, Kenneth M. Kletzer and Brian Pinto

NBER Working Paper No. 9190

September 2002

JEL No. F34, F36

\section{$\underline{\text { ABSTRACT }}$}

This paper argues that the frequent failure of the debt swaps is not an accident. Instead, it follows from fundamental forces driven by the market's assessment of the scarcity of fiscal revenue relative to the demand for fiscal outlays. It follows from the observation that arbitrage forces systematically impact prices in asset markets. Ignoring these price adjustments would lead to too optimistic an assessment of the gains from swaps or buybacks. A by-product of our paper is to highlight the perils of financial engineering that ignores the intertemporal constraints imposed by fiscal fundamentals. As a country approaches the range of partial default (either on domestic or external debt), swaps may not provide the expected breathing room and could even bring the crisis forward. Our methodology combines three independent themes: exchange rate crises as the manifestation of excessive monetary injections [Krugman-Flood-Garber], the fiscal theory of inflation [Sargent-Wallace (1981)], and sovereign debt. The integrated framework derives devaluation and external debt repudiation as part of a public-finance optimizing problem. We shows that under conditions similar to those which prevailed in Russia and Argentina prior to their meltdown, swaps are not just neutral, but could actually make the situation worse and even trigger a speculative attack. An unsettlingly clear implication of the model is that there may be very few options left once public debt reaches levels regarded as unsustainable in relation to fiscal fundamentals. Dollarization only makes matters worse, and pushes the debt write-down option to the fore.

Joshua Aizenman

Department of Economics

University of California, Santa Cruz

1156 High St.

Santa Cruz, CA 95064

and NBER

jaizen@cats.ucsc.edu

Kenneth M. Kletzer

Department of Economics

University of California, Santa Cruz

1156 High St.

Santa Cruz, CA 95064

kkletzer@cats.ucsc.edu
Brian Pinto

World Bank

1818 H. St, N.W.

Washington, DC 20433

bpinto2@worldbank.org 


\section{Introduction}

Russia's 1998 meltdown and Argentina's, which began in December 2001 and is still continuing, have a few notable features in common. Both count among the spectacular macroeconomic crises of the 1990s. In both cases, unsustainable public debt levels and dynamics eventually became the key issue. Furthermore, in both cases, there was a determined effort to save a fixed exchange rate, in the Russian case, a soft peg to the U.S. dollar, and in the Argentine case a constitutionally mandated currency-board based hard peg. Likewise, in both cases, there were factors that might have obscured the true underlying dynamics of public debt and contributed to an even bigger debt build-up than might have occurred otherwise. For Russia, these would include the real appreciation of the ruble over the three years prior to the crisis, which temporarily reduced the burden of foreign currency denominated public debt, and expected growth that never materialized. ${ }^{1}$ Likewise in Argentina, a growing disequilibrium in the real exchange rate after 1997 and the inclusion of large privatization proceeds as current revenues, especially in the early part of the 1990s, might have made public debt dynamics look much better than they were. ${ }^{2}$

There was yet another point of commonality, the one focused on in this paper: both countries attempted sovereign debt swaps with the intention of bolstering liquidity and avoiding meltdown. But even though these swaps, particularly the Russian one, were hailed with considerable fanfare and became an integral part of IFI led rescue packages, they did not work and might have even have backfired, as discussed below. ${ }^{3}$ This paper argues that the failure of the debt swaps is not an accident. Instead, it follows from fundamental forces driven by the market's assessment of the scarcity of fiscal revenue relative to the demand for fiscal outlays. Indeed, under certain conditions debt swaps may hasten the meltdown. The argument outlined in the paper resembles the one dealing with the limitations of debt buybacks (Bulow and Rogoff (1988)). It follows from the observation that arbitrage forces systematically impact prices in asset markets. Ignoring these price adjustments would lead to too optimistic an assessment of the gains from swaps or buybacks. A by-product of our paper is to highlight the perils of financial engineering that ignores the intertemporal constraints imposed by fiscal fundamentals. As a

\footnotetext{
${ }^{1}$ Kharas, Pinto and Ulatov (2001) contain a detailed analysis of the Russian meltdown.

${ }^{2}$ On the first point, see Perry and Serven (2002), on the second, Mussa (2002).

${ }^{3}$ The Russian swap was greeted with considerable and unqualified euphoria - see Kharas, Pinto and Ulatov (2001), although there was skepticism voiced about the Argentine swap, which was carried out as a lastditch measure.
} 
country approaches the range of partial default (either on domestic or external debt), swaps may not provide the expected breathing room and could even bring the crisis forward. ${ }^{4}$

Our methodology combines three independent themes: exchange rate crises as the manifestation of excessive monetary injections [Krugman-Flood-Garber], the fiscal theory of inflation [Sargent-Wallace (1981)], and sovereign debt. The integrated framework derives devaluation and external debt repudiation as part of a public-finance optimizing problem. It allows re-examining some of the dynamics of crises by combining S-W with KFG. We illustrate the usefulness of this approach by focusing on a narrow issue - the welfare effects of debt swaps. Yet, the framework can be used to address other policy issues.

The main results of the paper are as follows. First, it shows that under conditions similar to those which prevailed in Russia and Argentina prior to their meltdown, swaps are not just neutral along the lines of the Modigliani-Miller theorem, but could actually make the situation worse and even trigger a speculative attack. ${ }^{5}$ This result is developed in the context of a model that allows for multiple states of nature. "Good states" are those where growth and taxes are adequate to meet debt service payments, while "bad states" are those where growth and taxes are not enough and a devaluation is needed to restore fiscal solvency. Public debt levels and the currency composition are chosen keeping in mind fiscal constraints and inflation aversion, and are impacted by the initial debt. The usual motive for a debt exchange is the high interest differential between domestic currency (peso) debt and foreign currency (dollar) debt with a swap attempting to lower the share of peso debt. ${ }^{6}$ We show that such swaps actually hurt in bad states because they lower the base for the inflation tax and require an even bigger devaluation in such states. The rise in the expected level of devaluation then raises both the interest differential as

\footnotetext{
${ }^{4}$ If fiscal fundamentals are strong and public debt sustainability is not an issue, a debt exchange that lengthens maturity can be beneficial, as Korea's experience showed. In March 1998, Korea managed to lengthen its banks' foreign debt supported by a government guarantee, a move that is credited with lowering interest rates and stabilizing the exchange rate. However, the guarantee would not have meant much if fiscal and public debt conditions were weak. For a description of the exchange see Kim and Byeon (2001) and of its impact Chopra et al. (2001) Box 2.

${ }^{5}$ Simply put, the most basic version of the Modigliani-Miller theorem says that in a world of zero taxes, the value of a firm depends upon its cash flows and not how these are divided up between debt and equity, i.e., the composition of liabilities is irrelevant. In an ex post review of the Russian case, Stanley Fischer, then first deputy managing director of the IMF, expressed skepticism that a "market-friendly restructuring alone can fundamentally change a country's debt dynamics. Such restructurings take place at market prices, and thus almost by definition, do not significantly change the present value of the country's debt obligations....". See Comments and Discussion, Kharas et al. (2001).

${ }^{6}$ The Argentine swap was not a currency swap, but a maturity swap designed to lengthen debt. The Russian swap was both a maturity and currency swap.
} 
well as the shadow exchange rate - quite the opposite of the intended effect. Second, the multiple state approach used here allows a natural interpretation of IFI-led rescue packages as attempting to raise the probability of good states at the expense of bad states. It thus provides a way of integrating first and second generation models with their respective emphasis on fundamentals and credit rationing on the one hand and multiple equilibria and confidence on the other. Third, an unsettlingly clear implication of the model is that there may be very few options and only a limited role for IFIs once public debt reaches levels regarded as unsustainable in relation to fiscal fundamentals. Dollarization only makes matters worse, and pushes the debt write-down option to the fore.

The next section presents the Russian and Argentine debt swaps. This is followed by the development of an analytical model and interpretation of the Russian and Argentine experience in its context. The last section concludes.

\section{The Debt Swaps}

We first present the Russian swap and attendant circumstances. By May 1998, Russia's public debt, which was 50 percent of GDP at the end of 1997, was on a clearly unsustainable course. The marginal composite (ruble plus foreign) real interest rate was 27 percent, while growth prospects had been downgraded to zero. Tax collections had consistently fallen short of targets and oil prices were falling. There were in addition several serious fiscal and structural problems that had not been resolved. Russia's market indicators took a sharp turn for the worse, with spreads on its eurobonds and yields on its ruble treasury bills (GKOs) jumping upwards as the Indonesian political and financial crisis erupted in mid-May. Approximately $\$ 11$ billion of foreign exchange resources (reserve depletion plus new borrowings) had been used in the defense of the ruble from November 1, 1997, when the Asian crisis first spilled over, to end-May 1998, amounting to 5 percent of post-crisis 1999 GDP. International liquidity had been depleted, with gross foreign exchange reserves having fallen to only 12 percent of GKOs plus broad money by May end. Discussions with the IFIs had been in train throughout the year, and towards the end of June, intensified into negotiations on an emergency package, which was announced on July 13. It had three components: : (i) fiscal and structural reforms; (ii) a \$22.6 billion financing package including an immediate liquidity injection of $\$ 5.5$ billion (compared to gross foreign exchange reserves at the time of about $\$ 15$ billion); and (iii) a swap out of domestic debt (short-term ruble treasury bills or GKOs) into long-maturity dollar eurobonds (the "GKO-eurobond swap"). The 
liquidity injection into reserves and swap were meant to ease liquidity pressures and lower interest costs, thereby starting a virtuous cycle that by simultaneously relaxing fiscal constraints and lowering the probability of devaluation, would reduce ruble interest rates and place public debt on a downward trajectory.

Approximately $\$ 40$ billion by face value and $\$ 32.3$ billion by market value at prevailing exchange rates were eligible under the swap, which was hailed by market analysts as "The Great Ruble/Dollar Debt Swap" and as the "most positive aspect of the program". 7 Those wanting to convert would receive an equal amount by market value of 7-year and 20-year dollar eurobonds. They were asked to bid by quoting a single spread for both eurobonds, but with a benchmark of US Treasury May 2008 for the 7-year bonds and August 2027 for the 20-year bonds. MOF announced a minimum spread of 837.5 basis points. The bid results were announced on July 20 , 1998. At the maximum spread of 940 bps chosen by MOF, the total face value of eurobonds to be issued was $\$ 6.4$ billion, of which $\$ 0.5$ billion were new money bonds, and $\$ 5.94$ billion pertained to the GKO swap. ${ }^{8}$ The bonds were sold at a steep discount, at a price of 73.8 percent, so that the proceeds available for GKO redemptions were $\$ 4.4$ billion (5.94x0.738).

It thus turned out that there was not much demand for the eurobonds - only $\$ 4.4$ billion worth of GKOs were tendered, compared to $\$ 32$ billion of ruble debt maturing over the second half of 1998. This indicated that the bulk of GKO holders preferred to hold on to 1-4 month paper yielding 50 percent or more than swapping into long-term dollar-denominated bonds yielding 15 percent, indicating concerns about default risk as well as an implicit assessment that the peg would last for the next few months. However, the meltdown occurred less than a month later.

The situation began unraveling soon after the swap was completed, with both devaluation and default risk, measured by a decomposition of GKO yields, jumping up sharply. It was discovered that there was no demand from long-term buyers for the eurobonds created by the swap; and the large increase in dollar denominated debt interacted negatively with Russian bank exposures to Russian government dollar-denominated paper, making them vulnerable to margin

\footnotetext{
${ }^{7}$ MFK Renaissance, “The Great Ruble/Dollar Debt Swap”, Fixed Income Update, July 14, 1998; Brunswick Warburg, "Does IMF package mark the end of the ruble crisis?" July 14, 1998. However, the risk of unloading a large volume of Russian dollar debt on to a skittish market adding to pressure from sales by cash-strapped banks was noted in the MFK Renaissance report.

${ }^{8}$ For comparison, the spread on the 10-year Indonesian eurobond was 160 basis points LOWER than that on the 10-year Russian eurobond the day the swap was completed. Indonesia was at the time in the throes of a severe political and financial crisis.
} 
calls that required they liquidate their holdings of government debt. As GKOs were the most risky asset, exit intensified, leading to the meltdown.

The Argentine debt swap was similarly concluded after months of market concern about fiscal fundamentals and even outright default. ${ }^{9}$ By the end of 2000, public debt stood at 55 percent of GDP but would have been considerably higher if corrected for real exchange rate overvaluation, as very little debt was peso-denominated. In late 2000, sovereign bond spreads were 750 basis points above US treasuries and broke through 1000 basis points by March 2001 . Market analysts were openly discussing default by late 2000 . A $\$ 40$ billion IMF package was negotiated in December 2000 to stave off default and restore market confidence; but growth faltered and by March 2001 the market appeared to have concluded that the fiscal and debt situation was not salvageable. While Argentina had little short-term debt, its projected financing requirements were \$22 billion per year over 2001-2005 provided primary fiscal surpluses were large enough to stabilize the public debt to GDP ratio - and this would have required primary fiscal surpluses of at least 4 percent of GDP, which was not credible given the track record. Against this background, a \$29.5 billion debt "mega" swap was concluded over June 1-4 2001 to extend maturities. This voluntary swap, which enabled Argentina to postpone over $\$ 16$ billion in debt service payments between 2001 and 2005 - relatively small compared to financing requirements of $\$ 110$ billion - was greeted enthusiastically by investors according to press reports. ${ }^{10}$ Perhaps the most damaging aspect of the swap was that it was concluded at a spread of close to 1100 basis points, whereas calculations showed that at spreads of over 1000 basis points Argentina's debt dynamics were "virtually hopeless". ${ }^{11}$ Indeed, after the swap, meltdown proceeded as tax collections continued to flag, bond spreads rose even further and bank runs intensified because of concerns about sustainability of the currency-board-based peg.

Before proceeding to the analytical model, we briefly examine the intuition underlying the above swaps. The one for the Russian swap is more compelling. With GKO yields at 50 percent or more and eurobonds in the 13-15 percent range, a \$20 billion swap from GKOs into eurobonds would save $\$ 7.5$ billion per year, or about 2 percent of pre-crisis GDP. This would mean a substantial lowering of the fiscal deficit as well as a much improved liquidity index. The

\footnotetext{
${ }^{9}$ The discussion here is based on Mussa (2002), Perry and Serven (2002) and de la Torre and Schmukler (2002).

${ }^{10}$ See, for example, FT.com "Argentina buys time for economy”, by Thomas Catan and Vincent Boland, June 5, 2001. David Mulford, international chairman at Credit Suisse First Boston, was cited as describing the swap as a new, market-led solution to sovereign debt crises that other governments would be watching. ${ }^{11}$ Mussa (2002) page 25.
} 
remaining GKO holders would feel more confident that their debt would now be serviced, and also that their chances of exit into dollars would be better, as there would be a smaller volume of GKOs competing for the same amount of reserves. As noted above, this seemingly plausible intuition turned out too good to be true. ${ }^{12}$

In the Argentine case, there was no prospect of improving the fiscal situation, because interest rates rose as a result of the swap. Liquidity may have temporarily improved, but public debt dynamics worsened. An easy way to see this is by looking at the inter-temporal budget constraint: the sum of primary fiscal surpluses discounted by the difference between the real interest rate and the growth rate of real output has to at least equal the initial debt to output ratio as a solvency condition. The rise in the real interest rate as a result of the swap (the price paid for lengthening maturity) lowers the present value of the primary surpluses. Assuming the private sector prices the swap so as to at least maintain the debt ratio in a present-value sense, the only way out is for fiscal retrenchment or a rise in growth. The swap does not help with either in an obvious manner.

\section{A Simple Analytical Model}

The Technical Appendix provides a minimal model, and applies it to the welfare consequences of swaps. We apply the insight of the fiscal theory of the inflation, emphasizing the implications of the intertemporal budget constraints in an economy where the inflation tax is the residual that adjusts to meet the fiscal shortfalls [see Sargent and Wallace (1981)]. ${ }^{13} \mathrm{We}$ integrate Sargent-Wallace's insight with Krugman-Flood-Garber's articulation of the conditions leading to currency crises, paying attention to the complications added by sovereign debt.

\footnotetext{
${ }_{12}^{12}$ For a discussion of how the GKO-eurobond swap triggered Russia's crisis, see KPU (2001).

13 In their 1981 paper "Some Unpleasant Monetarist Arithmetic", Sargent and Wallace looked at the effectiveness of monetary policy under a regime where a fiscal authority sets a stream of deficits. Hence, in their model the fiscal authority (treasury) dominates the monetary authority (the central bank) by imposing a deficit stream, which must necessarily be financed by the Central Bank or Treasury. The monetary authority is eventually forced to finance the debt through seignorage. Their analysis gives interesting results, showing that it may not be possible for the monetary authority to generate seignorage sufficient to cover the debt if the sequence of deficits is either "too big" or "too long". They also find that the ability of the monetary authority to control inflation, given these deficits, is drastically reduced. It is possible for tight money to have little effect now, and result in higher inflation later. One of their simulations even reveals a case where tight money leads to higher inflation both now and in the future.
} 
The model is a two period, a small open economy with a single tradable good. The government can issue short-term debt denominated in domestic or foreign currency. Hence, the public sector finances the first period's fiscal outlays by taxes, and by domestic and external borrowing. The government collects tax revenue to meet its debt repayment obligations and issues money. Tax revenues in the model correspond to the net revenues available for debt servicing after covering some top priority fiscal expenditure, i.e., to the primary fiscal balance. Taxes are implicitly distortionary, and we assume that the output cost of taxation is increasing in the tax revenue raised for debt servicing. The second period net tax revenue is stochastic. The inflation rate in the second period is solved as part of a public finance problem, where the inflation tax responds to the fiscal conditions that the government inherits, and the realized state of nature.

The public finance problem solved by the policy maker includes the options of partial defaults on internal debt (inflation) and on external debt (debt repudiation). Both options are costly. The authorities determine the second period inflation and the extent of foreign debt repudiation by optimizing a social welfare function. This objective function is representing social preferences that are decreasing in net tax revenue and in the inflation rate. The government has preferences towards price stability, which in the open small economy is equivalent to maintaining a fixed exchange rate. ${ }^{14}$ Hence, inflation (equivalently, a devaluation) would occur only if maintaining price stability is too costly.

The government faces an upper bound on its capacity to tax in each state in the second period. The cost of taxation varies with an exogenous state of nature - raising taxes is more costly, and the upper bound on feasible tax revenue is lower in worse states of nature. This formulation is based on the idea that output is subject to stochastic disturbances and that the marginal cost of tax revenue declines with output. The government enters the first period with a given stock of short-term debt and can choose to refinance its debt by exchanging domestic currency bonds for foreign currency bonds. In the second period, the government repays its debt after uncertainty regarding the state of nature is resolved. In each state of nature, authorities decide whether to abandon the exchange peg, and, if they do, they also choose the ex post money supply.

\footnotetext{
${ }^{14}$ Such an objective function may characterize a benevolent administration that maximizes the expected utility of consumers who demand public services, in an economy where raising taxes is costly.
} 
Under sovereign immunity, governments are encouraged to make debt payments by the possibility of indirect sanctions for not doing so. These sanctions usually take the form of reduced access to foreign trade or international credit markets. In models of sovereign debt, the costs of default are limited, so that there are upper bounds on the repayments that a government will make. These can be state contingent and lead to debt limits. Models of equilibrium debt renegotiation (for example, Kletzer and Wright [2000] or Bulow and Rogoff [1989]) imply that debt repayments will be increasing with output. These are game theoretic models with discrete punishments for devaluation from equilibrium. A very simple way to incorporate the renegotiation or restructuring of sovereign debt repayments is to add a fixed cost of debt repudiation. In addition, if the government devalues, it incurs another cost, whether it repudiates its debts subsequently or not. The government chooses the optimal policies in order to maximize its objective function, taking into account the costs associated with internal and external defaults (devaluation and foreign debt repudiation, respectively).

A detailed analysis of the above model is contained in the technical appendix. As some of the technicalities may obscure the underlying economic forces at work, the text that now follows presents a simplified framework. Specifically, it ignores sovereign risk and assumes, to start with, that direct taxes are exogenously given. These simplifications allow us to provide a sharp illustration of the economic forces as work. The economic insights of this discussion carry over to the more general case, as articulated in the technical appendix.

Let $D$ denote the real present value of the debt at the end of period 1, and $x$ the proportion of the outstanding debt issued in domestic currency (pesos) at the end of period 1. The exchange rate in period 1 is unity and the short-term peso interest rate, $i$, floats in period 1 , so that a debt swap is a change in $x$. The foreign price level is constant and equal to one. In the second period the domestic price level, $P_{s}$ in state of nature s, rises at the devaluation rate. We assume that Fisher interest parity holds in equilibrium. The foreign (dollar) risk free interest rate is $r$. This means that

$$
1+r=E\left(\frac{1+i}{P}\right)=(1+i) \sum_{s=1}^{N} \phi_{s} \frac{1}{P_{s}}=(1+i) E(1 / P)
$$

where there are $\mathrm{N}$ states of nature in the second period, occurring with probability $\phi_{s} ; \quad 1 \leq s \leq N$. 
The second period government revenue in state of nature $\mathrm{s}$ is the sum of net taxes $\left(T_{s}\right)$ plus seignorage, denoted by $\sigma$. Seignorage revenues are expressed as a function of the price level given the state of nature, $\sigma\left(P_{s}\right)$, by substituting out for the money supply from money demand. If the exchange remains fixed in period 2, then $\sigma\left(P_{s}\right)=\sigma_{s}(1)$. If $P_{s}>1$, then the price level in state $\mathrm{s}$ is determined by the devaluation rate, possibly following a speculative attack. In these circumstances the seignorage revenue may include the international reserves. ${ }^{15}$ Hence, total fiscal revenue is bounded by

$$
\text { (2) } T_{s}+\sigma\left(P_{s}\right)
$$

We define the state of nature according to the net tax revenue, such that $T_{1}<T_{2}<\ldots<T_{n}$ (where the ranking of the states of nature reflects the ranking of net tax revenues, which in turn may reflect the ranking of productivity and output).

Recalling that $x$ stands for the share of peso debt and applying Fisher parity (1), for a given debt, $D$, the fixed exchange rate regime is viable in state of nature $s$ if and only if

$$
T_{s}+\sigma_{s}(1) \geq(1+r) D\left((1-x)+x \frac{1}{E(1 / P)}\right) \text {. }
$$

Or, equivalently,

$$
T_{s}+\sigma_{s}(1) \geq(1+r) D\left(1+x \frac{i-r}{1+r}\right),
$$

where $i$ and $r$ are linked by (1). In the fixed exchange rate regime, higher expected inflation increases the cost of debt by the expected inflation premium times the share of domestic currency debt.

We start the analysis with a useful benchmark case, ignoring sovereign risk. The aversion to inflation implies that devaluations will take place only in bad enough states of nature. Hence, the equilibrium is characterized by a threshold state, where for states of nature below the threshold, lower states are associated with higher devaluations (reflecting greater reliance on the inflation tax). In states of nature above the threshold, taxes are plentiful, and there is no need to supplement the tax revenue with the inflation tax (hence the exchange rate remains fixed).

\footnotetext{
${ }^{15}$ With a speculative attack, the precise magnitude of the seignorage revenue depends on the policy of the central bank. For example, if the central bank will not use any reserves to defend, then $\sigma\left(P_{S}\right)$ equals the conventional seignorage: the proportionate rise in $\mathrm{M}$ needed to achieve money equilibrium at the price level $P_{S}$. On the other hand, if the central bank commits part of its reserves, $\mathrm{R}_{0}$, to defense, then $\sigma\left(P_{S}\right)$ includes the conventional seignorage plus the reserves committed, $\mathrm{R}_{0}$.
} 
To illustrate this, let us ignore for the moment the endogeneity of the seignorage revenue, assuming that $\sigma_{s}\left(P_{s}\right)=\bar{\sigma}_{s}$. We will relax this assumption shortly. Let us denote by $\mathrm{j}+1$ the threshold state of nature where debt repayment is sustainable under a fixed exchange rate. For states $s, s<j+1$,

$$
T_{s}+\bar{\sigma}_{s}<(1+r) D\left(1+x \frac{i-r}{1+r}\right)
$$

The scarcity of fiscal revenue in these states necessitates devaluation, at rates determined by the fiscal solvency constraint:

$$
T_{s}+\bar{\sigma}_{s}=(1+r) D\left(1+x\left[\frac{1}{P_{s}} \frac{1+i}{1+r}-1\right]\right), \mathrm{s}=1, \ldots, \mathrm{j} .
$$

The maximum debt associated with fixed exchange rate regime at the threshold state, $j+1$, is determined by

$$
T_{j+1}+\bar{\sigma}_{j+1}=(1+r) D\left(1+x \frac{i-r}{1+r}\right) .
$$

Henceforth we assume that the debt is set at the maximum level consistent with maintaining the fixed rate in state $j+1$. For states above the threshold, $s>j+1$, the fiscal revenue is plentiful. We assume that the authorities reimburse this surplus in a lump sum manner. Equations (6) and (7), plus the Fisher interest parity condition linking $i$ to $r$ provide us with a system of simultaneous equations that determines uniquely the devaluation rates in states $s(s=1, \ldots, j)$, and the debt. The resultant equilibrium is characterized by the following claim-

Claim 1: When seignorage revenues are exogenous, a debt swap that reduces peso debt and increases dollar debt, i.e., lowers $\mathrm{x}$, increases the devaluation rates in states below the threshold state $\mathrm{j}+1$, but does not affect the equilibrium aggregate debt level or the threshold state. It therefore does not impact the probability of devaluation for a given initial debt level, which continues to be given by $\sum_{s=1}^{j} \phi_{j}$.

We will illustrate this claim by showing that choosing the appropriate increases in devaluation in states $1, \ldots, j$ will suffice to restore fiscal balance in states $1, \ldots j+1$ at the initial debt, leaving the exchange rate pegged in states $j+1, \ldots, N$.

First, note that equation (6) can be rewritten as 
(6') $T_{s}+\bar{\sigma}_{s}=(1+r) D\left(1+x \frac{i-r}{1+r}\right)+D x(1+i)\left(\frac{1}{P_{s}}-1\right), \mathrm{s}=1, \ldots, \mathrm{j}$.

The first term on the RHS is the return to debt holders in the absence of devaluation, and is exactly the same as the RHS of equation (7). The second term is the capital loss induced by the devaluation on holders of domestic currency debt. Straightforward addition shows that $(1+r) D=\sum_{s=1}^{j} \phi_{s}\left(T_{s}+\bar{\sigma}_{s}\right)+\sum_{s=j+1}^{N} \phi_{s}\left(T_{j+1}+\bar{\sigma}_{j+1}\right)$, i.e., $D$ is independent of $x{ }^{16}$

Consider now a swap that lowers $\mathrm{x}$. This will help in states $s>j+1$ because of the premium paid on peso debt in these states but hurt in bad states $(s \leq j)$ where peso debt suffers a capital loss. Restoration of fiscal equilibrium in all states can be achieved as follows: applying the implicit function theorem to the last term on the RHS of (7) shows that if the return on pesos rises in accordance with the following equation, the incipient surplus in states $s>j+1$ will be eliminated:

$$
\Delta i=\frac{-(i-r)}{x} \Delta x
$$

where $\Delta x<0$ is the size of the swap. Similarly, noting that the first term on the RHS of (6') remains unchanged after peso interest rates rise following the swap as per (8), applying the implicit function theorem to the second term and using (8) gives:

$$
\frac{\Delta P_{s}}{P_{s}}=\left(1-P_{s}\right) \frac{(1+r)}{(1+i)} \frac{\Delta x}{x} .
$$

Equation (9) shows two things: first, the size of the increase in devaluation rises with the size of the swap; and second, the worse the state (the higher $P_{s}$ is to begin with) the larger the devaluation needed to restore equilibrium. ${ }^{17}$

\footnotetext{
${ }^{16}$ This also implies that $D$ is independent of the $\mathrm{P}_{\mathrm{s}}$ 's, which are endogenous to $x$, while maximal $D$ is independent of $x$.

${ }^{17}$ An alternative way of interpreting the above is as follows: if following the swap, devaluation rates in bad states are adjusted according to the rule in (9), then peso interest rates will rise in accordance with (8) to restore equilibrium in all the states 1 to $\mathrm{j}+1$.
} 
We now turn to the endogenous seignorage case. Seignorage increases - up to a point depending upon the inflation elasticity of money demand - with devaluation. Therefore, more resources are available in the "bad" states and imposing the same structure as earlier, it follows that $(1+r) D=\sum_{s=1}^{j} \phi_{s}\left(T_{s}+\sigma_{s}\left(P_{s}\right)\right)+\sum_{s=j+1}^{N} \phi_{s}\left(T_{j+1}+\sigma_{j+1}(1)\right)$, i.e., the sustainable level of $D$ can go up. Suppose now that a swap is engineered, i.e., $x$ is lowered. In this case, if for the same swap size, the devaluation rule in (9) is applied, surpluses will develop in states 1 to $\mathrm{j}$ because seignorage will increase. Alternatively, if a lower rate of devaluation is used, peso interest rates will rise by less than indicated by equation (8) so that a surplus develops in $\mathrm{j}+1$. By continuity, $D$ can rise as $x$ falls. But notice that this also means higher expected inflation, i.e., $E P_{s}$ rises.

Thus, replacing high nominal interest rate peso debt with low nominal interest rate dollar debt is a mixed blessing - it increases debt capacity, but also increases the expected devaluation. This in turn would trigger higher domestic interest rate and higher demand for foreign currency in period one. If the supply of international reserves is limited, it may also trigger a speculative attack in period one. In the context of the Flood-Garber-Krugman model, this will be the case if the swap increases the shadow exchange rate above the pegged exchange rate in period 1 . More specifically, suppose a Cagan demand for money:

$$
\log M-\log S=-\eta\left[E\left(\log P_{s}\right)-\log P\right],
$$

where $M$ denotes the relevant fundamentals (supply of money and output), $\eta$ is the semi elasticity of the demand for money, and $S$ is the first period price level. The shadow exchange rate in such an economy would be

$$
\log \widetilde{S}=\frac{1}{1+\eta} \log M+\frac{\eta}{1+\eta} E\left(\log P_{s}\right) .
$$

Suppose that prior to the swap, the shadow exchange rate was marginally below unity (= the fixed exchange rate). Attempts to swap domestic currency with foreign currency debt may increase the expected future price to levels leading to the eventual collapse of the fixed exchange rate in period 1 , as would be the case if accomplishing the swap would imply $\widetilde{S}>1$. The above discussion may be summarized as follows:

Claim 2: Allowing seignorage revenues to vary with the rate of inflation gives a determinate solution for the share of peso debt. When total debt $D$ is relatively low, the peg may be sustainable in all states of nature and all debt can be in pesos. However, once $D$ crosses a certain threshold, further increases in $D$ are associated with falling shares of peso debt and higher 
devaluation rates in states of nature associated with low tax revenue. In this case, a swap of peso debt for dollar debt (lowering $x$ ) will raise total debt, but at a cost - higher expected devaluation. Large enough increases in expected devaluation could trigger a speculative attack in period one. ${ }^{18}$

\section{An Illustrative Model for Claims 1 and 2}

\section{Exogenous Seignorage (Claim 1)}

We illustrate Claim 1 with the help of a simple example, with $\mathrm{N}=2$ and $\mathrm{j}=1$. In this case, letting $\pi_{1} \equiv P_{1}-1$ and noting that $P_{2}=1$, (6) and (7) reduce to:

$$
\text { a. } \quad T_{1}+\bar{\sigma}_{1}=(1+r) D\left(1-\phi_{2} \frac{x \pi_{1}}{1+\phi_{2} \pi_{1}}\right)
$$

$$
\text { b. } \quad T_{2}=(1+r) D\left(1+\phi_{1} \frac{x \pi_{1}}{1+\phi_{2} \pi_{1}}\right)
$$

where it is assumed seignorage is zero when the exchange rate remains fixed. For a given inflation and aggregate debt, higher peso debt share leads to a fiscal surplus in state 1, and fiscal deficit in state 2 because the impact of devaluation in state 1 is proportional to the share of peso debt and works in opposite directions in the two states. A higher devaluation (inflation rate) in state 1 reduces the value of debt in that state at a rate proportional to the difference between the actual and expected inflation (= the probability of state 2 times state 1 inflation); but increases the value of the debt in state 2 at a rate proportional to expected inflation (= the probability of state 1 times state 1 inflation).

For a given domestic currency debt $x$, system (12) solves for the devaluation rate in state 1 and total debt. Figure 1 characterizes the solution. The upward sloping bold curve traces the association between devaluation in state 1 and the total debt that solves the fiscal constraint in state 1 (equation 12a). Higher devaluation in that state induces greater capital loses to peso bond holders, generating a fiscal surplus, increasing the total debt associated with fiscal balance in state 1. The downward sloping curve traces the association between devaluation in state 1 and the total debt that satisfies the fiscal constraint in state 2 (equation 12b). This is the state where the exchange rate remains fixed. Higher devaluation in state 1 will increase expected inflation and the nominal interest rate, increasing thereby the fiscal cost in state 2 associated with peso debt. Hence, it will induce a drop in the total debt associated with fiscal balance in state 2 . The

\footnotetext{
${ }^{18}$ This is bad news for highly dollarized economies such as Argentina. They can borrow more provided the good state probability is high; but once this changes, there may be a much bigger inflationary collapse than with less dollarization - or if this is excessively costly, an outright default.
} 
equilibrium inflation and the debt are at the intersection of the curves. Panel a corresponds to the case where $\mathrm{x}=1$, whereas panel $\mathrm{b}$ corresponds to $\mathrm{x}=0.5$. Reducing the domestic currency debt share shifts both curves to the right: at a given debt, the lower share of domestic currency induces a fiscal deficit in state 1 , requiring greater devaluation in order to regain fiscal balance. The opposite happens in state 2 - the drop in the share of domestic debt reduces the capital losses due to expected devaluation that does not materialize in state 2, leading to fiscal surplus. Fiscal balance in state 2 is regained at a higher inflation. The two curves shift to the right at the same rate, implying a new equilibrium with the same debt level, but substantially higher devaluation rate in state 1 (inflation more than doubles from about 0.25 to about 0.56 ).

The intuition behind the above results follows from the inequality:

$$
\frac{1+i}{P_{1}}<1+r<1+i
$$

which basically says that ex post payments on peso debt in state 1 are less than those on dollar debt (same in both states) which in turn is less than ex post payments on peso debt in state $2 .{ }^{19}$ This inequality is key to explaining why debt swaps do not work when solvency is a concern.

\section{Endogenous seignorage (Claim 2)}

In equation (12) a, $\bar{\sigma}_{1}$ is replaced with $\sigma_{1}\left(\pi_{1}\right)$, which is concave in $\pi_{1}$, representing a seignorage Laffer curve. Linearizing around an existing fiscal equilibrium and assuming a swap size of $\Delta x<0$, we get:

$$
\Delta \pi_{1}=\frac{(1+r) D \pi_{1}}{1+\phi_{2} \pi_{1}} \frac{\Delta x}{\lambda} \text { and } \Delta D=\frac{\sigma_{1}^{\prime} D \phi_{1} \pi_{1}}{1+\phi_{2} \pi_{1}} \frac{\Delta x}{\lambda}
$$

where $\lambda=-\sigma_{1}^{\prime}\left(1+\frac{\phi_{1} x \pi_{1}}{1+\phi_{2} \pi_{1}}\right)-\frac{D(1+r) x}{\left(1+\phi_{2} \pi_{1}\right)^{2}}<0$. It follows from (14) that consistent with Claim 2, both bad state inflation and total debt go up to restore equilibrium when a swap that lowers peso debt $\left((\Delta x<0)\right.$ is engineered. ${ }^{20}$ Consistent with Claim 1, total debt remains the

${ }^{19}$ This follows directly from Fisher interest parity, namely, $1+i=\frac{(1+r) P_{1}}{\phi_{1}+\left(1-\phi_{1}\right) P_{1}}$.

${ }^{20} \mathrm{We}$ assume that inflation is less than the seignorage maximizing rate. 
same and $\Delta \pi_{1}$ rises to $-\pi_{1}\left(1+\phi_{2} \pi_{1}\right) \frac{\Delta x}{x}$ for a swap of the same size when seignorage is exogenous $\left(\sigma_{1}^{\prime}=0\right) .^{21}$

We now illustrate Claim 2 with the help of a two state example (see the Appendix for the general case). Suppose that the second period output is:

$$
Y_{s}=\left\{\begin{array}{lll}
1-\varepsilon & \operatorname{Pr} & \phi_{1} \\
1 & \operatorname{Pr} & \phi_{2}
\end{array} \quad, \phi_{1}+\phi_{2}=1\right.
$$

Seignorage is assumed to be given by a quadratic function ${ }^{22}$

$$
\sigma_{s}=k Y_{s}\left[\pi_{s}-0.5 \frac{\left(\pi_{s}\right)^{2}}{b}\right]
$$

where the inflation rate in state $\mathrm{s}$ is defined by $\pi_{s}=P_{s}-1$. Seignorage is maximized at

$$
\pi^{m}=b
$$

To start, let us assume that the tax rate is exogenously set at $t_{0}$. In these circumstances, tax revenue is proportional to productivity, and $T_{1}=T_{2}(1-\varepsilon)$. Suppose taxes are enough to repay debt in state of nature 2 without devaluation (hence, $\mathrm{j}=1$ ). If $T_{2}(1-\varepsilon)>(1+r) D$, the tax revenue suffices to cover the debt in state 1 , and there is no need to devalue [set seignorage and $\pi_{1}=0$ in (12 a)]. For debt levels above the tax revenue in state $\left.1\left[T_{2}(1-\varepsilon)<(1+r) D\right)\right]$, and for $T_{2}>(1+r) D\left[1+\frac{\phi_{1} \pi_{1}}{1+\phi_{2} \pi_{1}}\right]$, all the debt can be domestic currency denominated [set $x=1$ in (12 b)]. The inflation rate in state 1 is determined by the requirement of fiscal sustainability in state 1:

$$
T_{2}(1-\varepsilon)+k(1-\varepsilon)\left[\pi_{1}-0.5 \frac{\left(\pi_{1}\right)^{2}}{b}\right]=(1+r) D\left[1-\phi_{2} \frac{\pi_{1}}{1+\phi_{2} \pi_{1}}\right]
$$

If $T_{2}<(1+r) D\left[1+\frac{\phi_{1} \pi_{1}}{1+\phi_{2} \pi_{1}}\right]$, then $\mathrm{x}=1$ is not feasible -- it would impose a too high fiscal cost in state 2 - recall inequality (13). In these circumstances, $x$ and $\pi_{1}$ are determined by the following system:

\footnotetext{
${ }^{21}$ This expression is exactly the same as equation (9) above, using $P_{1}=1+\pi_{1}$ and noting that $(1+r) /(1+i)=\left(1+\phi_{2} \pi_{1}\right) /\left(1+\pi_{1}\right)$.

${ }^{22}$ To simplify the example, we ignore the seignorage associated with output growth.
} 
(18)

$$
\left\{\begin{array}{l}
T_{2}(1-\varepsilon)+k(1-\varepsilon)\left[\pi_{1}-0.5 \frac{\left(\pi_{1}\right)^{2}}{b}\right]=(1+r) D\left[1-x \frac{\phi_{2} \pi_{1}}{1+\phi_{2} \pi_{1}}\right] \\
T_{2}=(1+r) D\left[1+x \frac{\phi_{1} \pi_{1}}{1+\phi_{2} \pi_{1}}\right]
\end{array} .\right.
$$

Notice that higher inflation in $\mathrm{s}=1$ reduces the debt repayment in that state. In contrast, higher inflation in $\mathrm{s}=1$ increases the debt repayment in the state where the pegged exchange rate is maintained $[\mathrm{s}=2]$. Solving this system yields that, in the range of $\mathrm{D}$ associated with $0<x<1$,

$$
\pi_{1}=b-\sqrt{b^{2}+2 b \frac{T_{2}\left(1-\phi_{1} \varepsilon\right)-(1+r) D}{\phi_{1}(1-\varepsilon) k}} .
$$

The inflation is characterized by $\pi_{1}=\pi_{1}\left[T_{2} ;(1+r) D ; k ; \varepsilon\right]$.

Figure 2 captures a simulation of this quadratic example. The solid upward sloping curve reports the association between total debt $(D)$ and inflation. The dotted, downward sloping curve reports the association between the debt and the share of domestic currency debt, $x$. For low debt, the inflation rate is zero in all states of nature. For debt above 0.163 and below 0.203 the inflation rate in state one increase with the debt, and the entire debt is domestic currency denominated. Higher expected inflation increases the cost of serving the domestic currency debt in state 2. At a critical debt [about $\mathrm{D}=0.203$ ], the inflation in state 1 and the debt are high enough to "bump" the fiscal constraint in state 2 for $x=1$. Increasing the debt above that threshold requires lowering the share of the domestic currency debt and higher inflation. Above that threshold, the marginal impact of debt on inflation is larger than below the threshold. At debt level of about 0.236 the inflation in $\mathrm{s}=1$ reaches the level maximizing seignorage revenue in that state $(\pi=1)$, reaching the debt ceiling associated with $\mathrm{j}=1$. Allowing for foreign currency debt increases the debt ceiling, yet it comes with a cost - a rapid increase in inflation.

Our model can be readily extended to allow for endogenous determination of taxes. Specifically, the second period utility in state s can be approximated by

$$
Y_{0}\left(1+\delta_{s}\right)\left[1-\left\{0.5 c_{m}\left(\pi_{s}\right)^{2}+\frac{0.5\left(t_{s}\right)^{2}}{\lambda}+d \chi\right\}\right],
$$

where $\chi$ is the indicator function, having a value of one if devaluation takes place in state $\mathrm{s}$, and zero otherwise; $0.5 c_{m}$ measures the welfare cost of inflation as a fraction of the GDP; and $\delta_{s}$ is the productivity shock in state s. This specification recognizes that devaluation is associated with 
a cost $d$, in addition to the direct costs of inflation [see Obstfeld (1996) for further discussion]. The actual tax rate and inflation rate in state $\mathrm{s}$ are determined by maximizing the second period utility subject to the budget constraint. For our two state of nature example discussed above, in the range associated with $\mathrm{x}<1$ in state $\mathrm{s}=1$, the budget constraints are

$$
\left\{\begin{array}{l}
Y_{0}(1-\varepsilon)\left\{t_{1}+k\left[\pi_{1}-0.5 \frac{\left(\pi_{1}\right)^{2}}{b}\right]\right\}=(1+r) D\left[1-x \frac{\phi_{2} \pi_{1}}{1+\phi_{2} \pi_{1}}\right] \\
Y_{0}(1-\varepsilon) t_{2}=(1+r) D\left[1+x \frac{\phi_{1} \pi_{1}}{1+\phi_{2} \pi_{1}}\right]
\end{array} .\right.
$$

The authorities determine the tax rate and the inflation in $\mathrm{s}=1\left(t_{1} ; \pi_{1}\right)$ by maximizing $(20)$ subject to the appropriate budget constraint (the first line in 21). The resultant association between the inflation and the tax rate in $\mathrm{s}=1$ is positive and non-linear:

$$
\frac{t_{1}}{\frac{\pi_{1}}{1-\left(\pi_{1} / b\right)}}=\frac{k / c_{m}}{\lambda} .
$$

The resultant equilibrium is similar to the one described in Figure 2, with the modification that in state 1 the tax rate and the inflation rate are endogenously determined.

\section{Balance sheet surprises}

Revisiting equation (12) for the endogenous seignorage case, we note that a rise in state 1 inflation will have three effects: (i) state 1 seignorage will increase; (ii) so will peso interest rates; and (iii) the size of the capital loss (gain to the government) on peso debt for given $D$ and $x$ will rise. Letting $F S_{1}$ denote state 1 fiscal surplus (LHS of (12) a. with endogenous seignorage minus RHS), its derivative with respect to state 1 inflation is:

$$
\partial F S_{1} / \partial \pi_{1}=\sigma_{1}^{\prime}+(1+r) D \phi_{2} x\left[\frac{1}{\left(1+\phi_{2} \pi_{1}\right)^{2}}\right]
$$

The first term on the RHS captures (i) above, while the second term is the net effect of (ii) and (iii). Given the concavity of $\sigma_{1}($.$) , it is obvious from (23) that the level of state 1$ inflation that 
would maximize state 1 fiscal surplus will exceed the seignorage maximizing level because of the additional capital loss on peso debt. Now suppose that there is unanticipated fiscal cost associated with a devaluation (and hence inflation). This can be thought of as a bailout induced by political pressure, forcing the government to support the banking system to make its balance sheet whole. Let $\beta\left(\pi_{1}\right)$ denote the size of the resultant fiscal cost. We assume reasonably that the size of this unanticipated balance sheet problem increases linearly with state 1 inflation, as for any given balance sheet mismatch, the situation would be worse with a larger devaluation. In Figure $3, \Gamma\left(\pi_{1}\right)$ depicts the sum of seignorage revenues and the capital loss on peso debt and $\beta\left(\pi_{1}\right)$ the fiscal cost of the balance sheet problem. Even though $\bar{\pi}_{1}$ maximizes seignorage plus the capital loss, the government will want to avoid a "free-fall" of the exchange rate above $\left(1+\bar{\pi}_{1}\right)$ because of the balance sheet problem. If now it turns out that $F S_{1}\left(\bar{\pi}_{1}\right)<0$, devaluation will not suffice to restore fiscal solvency in state 1 and in this case, a default and debt restructuring may become inevitable. In this case, if the private sector is expecting state 1 inflation to exceed $\bar{\pi}_{1}$ (because it does not anticipate the magnitude of the balance sheet problem), the period 1 differential interest differential $(i-r)$ would be very high and a swap to lower peso debt might appear attractive; but it will only make matters worse (because $\left.\frac{\partial F S_{1}}{\partial x}>0\right)$, increasing the need for a debt reduction or default.

\section{Interpretation of Russian and Argentine Experience}

The debt swaps in Russia 1998 and Argentina 2001 took place in the following circumstances: (i) market perceptions of default risk were high and debt rollovers were a problem. Bond spreads were in excess of 700 basis points for the few months preceding the swap, and the swaps were concluded at spreads of slightly less than 1000 basis points (Russia) or exceeding it (Argentina). Such spreads have almost invariably portended eventual crisis - a large devaluation at least as in Russia 1998, Brazil 1999, Turkey 2001, Argentina 2001, if not default as well as in Russia and Argentina; (ii) public debt was on an unsustainable course and growth was flagging; and (iii) the IFIs were putting together rescue packages with a combination of fiscal-structural reforms and liquidity enhancing loans. In other words there was a determined effort to overcome negative market sentiment and save the fixed exchange rate peg. 
We return to Figure 2 to interpret the Russian and Argentine experience. Ignoring the balance sheet problem for the moment, Figure 2 has a straightforward interpretation: when total debt is low, currency composition may not matter and all the debt can be held in pesos. However, as debt grows fiscal solvency in the bad state (low growth and taxes) may become a problem and beyond a point like A in Figure 2, a bad state devaluation will be needed to restore solvency in that state. This will raise peso interest rates, an effect that will be offset by higher seignorage plus capital losses on peso debt through devaluation (which we shall refer to collectively as the inflation tax) should the bad state materialize, but reduce the good state fiscal surplus because the exchange rate remains pegged in this state. The shadow exchange rate will rise. As debt continues to rise and reaches the point B in Figure 2, the fiscal surplus in the good state disappears because of the growing peso-dollar interest differential. Beyond B, solvency requires both a fall in the share of peso debt, and a faster rate of devaluation in the bad state because the base of the inflation tax shrinks. This further widens the peso-dollar interest differential. If a swap is attempted in these circumstances, it will push inflation towards the seignorage maximizing rate and could precipitate the collapse of the fixed peg. Hence, the authorities may find it more attractive to dilute the burden of public debt by levying a capital tax on holders of its debt. A partial default would reduce expected inflation.

Consider now a case where $D$ is very high and $x$ is small, i.e., public debt is high and dollarized as in the case of Argentina so that the base for the inflation tax is low. In this case a currency swap (lowering peso debt) may not help much, as it would rapidly raise bad state inflation - which might explain the debate over "pesifying" dollar liabilities in Argentina. ${ }^{23}$ It is a way of raising the base of the inflation tax and lowering expected inflation. If at the same time there is a balance sheet problem, then the only way to restore fiscal solvency might be through a debt write down. In the Russian case, $D$ was also high, but $x$ at 0.3 was also relatively high. With a very high ruble-dollar interest differential, a swap appeared attractive, but according to the model would only make matters worse by increasing bad state inflation and hence the interest differential. It would also raise the shadow exchange rate and trigger a speculative attack. While there were other factors also at play in Russia - such as the liquidity injection to reserves in the form of senior IFI loans and the interaction of the swap with bank balance sheets as discussed above - the developments after the swap conform to the predictions of our model.

\footnotetext{
${ }^{23}$ See for example de la Torre and Schmukler (2002).
} 
A puzzle that remains is why creditors let debt levels go up to such high levels in the first place. As noted above, there were factors at play both in Argentina and Russia which made public debt dynamics look much better than they actually were. Another possibility is that the probability of a bad state went up, in Russia's case because of the East Asian crisis and falling oil prices, and in Argentina's case because of contagion from both Russia and Brazil. This would lower what are regarded as sustainable public debt levels and raise both the size of expected devaluation and domestic interest rates. This may strengthen the motivation for a swap out of domestic debt; but this will only make matters worse for the bad state to which a higher probability is now assigned thereby hastening meltdown.

\section{Concluding Remarks}

Our model tries to explain why debt swaps do not work when fiscal fundamentals are weak in spite of their intuitive appeal. In so doing, it sheds light on the fundamental nature of the macroeconomic crises that Russia and Argentina experienced. The model combines in a simple way the inter-temporal budget constraint of the government with the arbitrage-based pricing of peso and dollar debt in the context of a pegged exchange rate. It shows that attempts to lower the share of high-yielding peso debt would help in good states where taxes are adequate to service debt and the peg remains intact; but hurt in bad states where taxes need to be augmented by the inflation tax and a devaluation is needed to restore fiscal solvency. In other words, instead of protecting the peg, the swap increases the expected rate of devaluation which in turn could hasten its abandonment. The first part is analogous to the Sargent-Wallace argument, whereby tighter money actually raises expected inflation given an underlying fiscal imbalance and growing indebtedness. The second part flows from the observation that the increase in domestic interest rates linked to the rise of the expected rate of devaluation lowers the demand for money, raising the shadow exchange rate. If this rises sufficiently fast and exceeds the level of the fixed peg, it will prompt a speculative attack a la Krugman-Flood-Garber.

So then why are swaps included as part of rescue packages? We note two possibilities: first, there may be a belief that an interest rate arbitrage is available, i.e., that Fisher parity does not hold. Second, the government may believe that as a result of the IFI rescue and reforms package it can dramatically lower the probability of a bad state. In other words, the reduction in the share of peso debt is accompanied by a fall in the probability of the bad state so that expected devaluation does not go up and peso interest rates could even fall, setting of a virtuous cycle of 
higher growth and falling interest rates. ${ }^{24}$ Our paper argues that the chances this will happen given high public debt and bad fiscal fundamentals are low at best. But these are precisely the circumstances in which countries that undertake the swap as a last resort, hoping to avoid a meltdown. Consequently, our model implies that swaps may have harmful effects precisely in the circumstances when they tend to be implemented as part of a rescue package. The very fact that the government's inter-temporal budget constraint is binding means the market has already factored in the possibility of correcting the fiscal fundamentals and found them inadequate. In these situations, attempting to shore up liquidity by a combination of liquidity injections from the IFIs (which means a matching increase in public debt, and more senior debt at that) and debt swaps then only worsens further the fiscal situation in the eyes of the private sector. Indeed, it may also raise the specter of moral hazard: IFI entry is the best time to exit. ${ }^{25}$ The overall conclusion is that there is not much IFIs can do when default risk reaches a certain point, and non-market based debt restructuring may be the only option.

Our model abstracted from several important issues. Among the topics left for extensions:

- Adding non-traded goods. This will allow us to understand the impact of real exchange rate adjustments on the exposure to crisis, and to evaluation the balance sheet effects of swaps.

- Adding periods, in order to investigate the intertemporal dynamics leading to a crisis.

- Moral hazard associated with swaps may be added by introducing an IFI loan that goes into reserves; it does not change the net debt position of the government, but could worsen the fiscal situation if reserves carry a lower interest rate than IFI loans and "demote" other loans if IFI loans are senior. This extension will provide a linkage between our model and the third generation models of crises.

\footnotetext{
24 This follows directly from Fisher interest parity.

25 This point is made forcefully in the Russian case of 1998 by Kharas et al. (2001).
} 


\section{Appendix}

This appendix extends the model of debt swaps to the case in which the government chooses its fiscal, financial and monetary policies to maximize a social welfare function. It first presents some completion of the analysis in the text. As before, the government collects tax and seignorage revenues to meet its debt repayment obligations, and we abstract from other aspects of fiscal policy, such as public non-interest expenditures. Taxes are implicitly distortionary, and the output cost of taxation is assumed to be increasing in tax revenue raised. Authorities also have an objective function representing social preferences that is decreasing in net tax revenue and in the inflation rate. The cost of taxation varies with an exogenous state of nature, representing the idea that output is subject to stochastic disturbances and the marginal cost of tax revenue declines with output. The government will also be allowed to default on debt (but sovereign default is costly).

\section{The general model of debt swaps}

We begin with the mechanics of debt exchanges in the basic model and develop our analysis by extending the model. For now, the government cannot default on foreign currency debt and has already reached its capacity to repay. There are two dates and $\mathrm{N}$ states of nature in the second period, such that $T_{1}<T_{2}<\ldots<T_{N}$.

Fisher interest parity,

$$
1+r=E\left(\frac{1+i}{P}\right)=(1+i) \sum_{s=1}^{N} \phi_{s} \frac{1}{P_{s}}=(1+i) E(1 / P),
$$

holds in equilibrium, and the budget constraint for the government in state $\mathrm{s}$ in period 2 is given by

$$
T_{s}+\sigma\left(P_{s}\right) \geq(1+r) b+(1+i) \frac{B}{P_{s}},
$$

where $b$ is the outstanding stock of dollar debt and $B$ is the outstanding stock of peso debt. We rewrite this constraint to obtain the expressions used in the text, as

$$
T_{s}+\sigma_{s}\left(P_{s}\right) \geq(1+r) D\left((1-x)+x \frac{1}{P_{s} E(1 / P)}\right),
$$

where $D=b+B$ and $x$ is the proportion of outstanding debt issued in domestic currency at the end of period 1. When these inequalities are binding, they solve for the minimum state-contingent devaluation necessary to maintain government solvency, so that they give the solution for a government that is inflation-averse and is constrained not to default.

For the exogenous seignorage revenues case, the $\mathrm{j}+1$ conditions,

$$
T_{s}+\bar{\sigma}_{s}=(1+r) D\left((1-x)+x \frac{1}{P_{s} E(1 / P)}\right), \text { for } \mathrm{s}=1, \ldots, \mathrm{j},
$$

and

$$
T_{j+1}+\bar{\sigma}_{j+1}=(1+r) D\left((1-x)+x \frac{1}{P_{s} E(1 / P)}\right),
$$

determine the $\mathrm{j}+1$ variables, $P_{1}, \ldots, P_{j}$, and $\mathrm{D}$ given $\mathrm{x}$. Calculating total expected revenues, we have

$$
(1+r) D=\sum_{s=1}^{j} \phi_{s}\left(T_{s}+\bar{\sigma}_{s}\right)+\sum_{s=j+1}^{N} \phi_{s}\left(T_{j+1}+\bar{\sigma}_{j+1}\right),
$$


so that $\mathrm{D}$ is independent of $\mathrm{x}$. Changing $\mathrm{x}$ only affects the post-devaluation price levels and not the capacity of the government to service its debt or avoid devaluation.

For the case of endogenous seignorage revenues, the conditions for solvency are

$$
\begin{aligned}
& T_{s}+\sigma_{s}\left(P_{s}\right)=(1+r) D\left((1-x)+x \frac{1}{P_{s} E(1 / P)}\right), \text { for } \mathrm{s}=1, \ldots, \mathrm{j}, \\
& T_{j+1}+\sigma_{j+1}(1)=(1+r) D\left((1-x)+x \frac{1}{P_{s} E(1 / P)}\right)
\end{aligned}
$$

and

$$
(1+r) D=\sum_{s=1}^{j} \phi_{s}\left(T_{s}+\sigma_{s}\left(P_{s}\right)\right)+\sum_{s=j+1}^{N} \phi_{s}\left(T_{j+1}+\sigma_{j+1}(1)\right) .
$$

These, now $\mathrm{j}+2$ equations in $\mathrm{j}+2$ variables, solve for $\mathrm{x}$ as a function of $\mathrm{D}$. A decrease in $\mathrm{x}$ leads to a rise in $P_{s}$ for $\mathrm{s}$ less than $\mathrm{j}+1$. This increases seignorage revenues on the left-hand side of equation (a7) as long as $\sigma_{s}{ }^{\prime}\left(P_{s}\right)>0$. Equation (a9) shows that this allows an increase in D subject to the no-default constraint. In this case, the nominal interest rate does not increase by as much as in the exogenous seignorage case, so that equation (a8) will continue to be satisfied with a lower $\mathrm{x}$ and higher $\mathrm{D}$. When $\mathrm{D}$ is maximized, $\sigma_{s}{ }^{\prime}\left(P_{s}\right)=0$, for at least one state $\mathrm{s}$ less than $\mathrm{j}+1$.

\section{Endogenizing fiscal and monetary policy}

Policy objectives for the government can be introduced as marginal costs of distortionary taxes and inflation. The social costs of distortionary taxes and of inflation are assumed to be additively separable and are represented by the two functions, $w_{s}\left(T_{s}\right)$ and $v_{s}\left(P_{s}\right)$, respectively, where $w_{s}{ }^{\prime}\left(T_{s}\right)$ and $v_{s}{ }^{\prime}\left(P_{s}\right)$ are each positive and increasing in their respective arguments. For any given values of $\mathrm{T}$ and $\mathrm{P}$, respectively, these marginal costs are assumed to be decreasing in $\mathrm{s}$. There will also be an upper bound on the tax revenue that the government can raise in any state, $\overline{T_{s}}$. For convenience, we assume that $\lim _{T_{s} \rightarrow T_{s}} w_{s}{ }^{\prime}\left(T_{s}\right)=\infty$. To represent the government's incentive to keep the exchange rate fixed in some states, a fixed cost, $d$, to depreciating at any rate is also adopted.

The government chooses it contingent policy to minimize its loss function,

$$
\sum_{s=1}^{N} \phi_{s} \min \left\{w_{s}\left(\hat{T}_{s}\right), \min _{T_{s}, P_{s}}\left\{w_{s}\left(T_{s}\right)+v_{s}\left(P_{s}\right)+d\right\}\right\}
$$

subject to the constraints

$$
T_{s}+\sigma_{s}\left(P_{s}\right) \geq(1+r) D\left((1-x)+x \frac{1}{P_{s} E(1 / P)}\right)
$$

and

$$
\hat{T}_{s}+\sigma_{s}(1) \geq(1+r) D\left((1-x)+x \frac{1}{E(1 / P)}\right),
$$

for $\mathrm{s}=1, \ldots, \mathrm{N}$, given $\mathrm{D}$.

The first-order conditions are 
(a13)

$$
\begin{aligned}
& w_{s}{ }^{\prime}\left(T_{s}\right)=\frac{v_{s}^{\prime}\left(P_{s}\right)}{\sigma_{s}{ }^{\prime}\left(P_{s}\right)}, \text { for } \mathrm{s}=1, \ldots, \mathrm{j}, \\
& w_{s}{ }^{\prime}\left(T_{s}\right)=w_{s^{\prime}}{ }^{\prime}\left(T_{s^{\prime}}\right)=w_{s^{\prime \prime}}{ }^{\prime}\left(\hat{T}_{s^{\prime \prime}}\right), \text { for } \mathrm{s}, \mathrm{s}{ }^{\prime}=1, \ldots, \mathrm{j}, \text { and } \mathrm{s}{ }^{\prime}=\mathrm{j}+1, \ldots, \mathrm{N}, \\
& T_{s}+\sigma_{s}\left(P_{s}\right)=(1+r) D\left((1-x)+x \frac{1}{P_{s} E(1 / P)}\right), \text { for } \mathrm{s}=1, \ldots, \mathrm{j},
\end{aligned}
$$

and

$$
\hat{T}_{s}+\sigma_{s}(1)=(1+r) D\left((1-x)+x \frac{1}{E(1 / P)}\right), \text { for } \mathrm{s}=\mathrm{j}+1, \ldots, \mathrm{N},
$$

where $E\left(\frac{1}{P}\right)=\sum_{s=1}^{j} \phi_{s} \frac{1}{P_{s}}+\sum_{s=j+1}^{N} \phi_{s}$. The solvency condition, equation (a9) also holds in this equilibrium. Condition (a14) is tax smoothing; note that conditions (a13) and (a14) imply that the marginal cost of the inflation tax, $\frac{v_{s}{ }^{\prime}\left(P_{s}\right)}{\sigma_{s}{ }^{\prime}\left(P_{s}\right)}$, is also smoothed across all states $\mathrm{s}=1, \ldots, \mathrm{j}$. The choice of state $\mathrm{j}$ is determined by comparing $w_{s}\left(\hat{T}_{s}\right)$ to $w_{s}\left(T_{s}\right)+v_{s}\left(P_{s}\right)+d$ for states $\mathrm{j}$ and $\mathrm{j}+1$ where $\hat{T}_{s}$ is the tax revenue required if the price level is fixed equal to one and $T_{s}$ is the tax revenue required when the price level exceeds one and satisfies the first-order condition (a13). Seignorage revenues are not maximized in any state in equilibrium here; that is, $\sigma_{s}{ }^{\prime}\left(P_{s}\right)>0$.

This optimization problem solves for the probability that the exchange rate peg lasts through the second period, $\sum_{s=j+1}^{N} \phi_{s}$, the allocation of debt across currencies, $\mathrm{x}$, and the trade-off between conventional taxes and inflation taxes conditional on abandoning the exchange rate peg. This solution implicitly assumes that the shadow exchange rate in period 1 is less than one so that the peg can be maintained with positive probability in period 2 . We can also observe that the upper bound for outstanding debt, $D$, is reached when $j+1=N$, although this will exceed the optimal debt level in the general case.

\section{Sovereign defaults}

Under sovereign immunity, governments have the incentive to make debt payments because they face the possibility of indirect sanctions for not doing so. These sanctions usually take the form of reduced access to foreign trade or international credit markets. In models of sovereign debt, the costs of default are limited, so that there are upper bounds on the repayments that a government will make. These can be state contingent and lead to debt limits. Our model already incorporates upper bounds on the willingness of the government to raise taxes for debt repayments given by the $\overline{T_{s}}$. It is also realistic to bound seignorage revenues from above.

Models of equilibrium debt renegotiation (for example, Kletzer and Wright [2000] or Bulow and Rogoff [1989]) imply that debt repayments will be increasing with output. These are game theoretic models with discrete punishments for deviation from equilibrium. A very simple way to incorporate the renegotiation or restructuring of sovereign debt repayments is to add a fixed cost of debt repudiation, $\mathrm{f}$. Under this assumption, the government is willing to raise revenues through either conventional distortionary taxes or seignorage for debt service that satisfy

$$
\text { (a17) } w_{s}\left(T_{s}\right) \leq f,
$$

under the fixed exchange rate regime, or 


$$
w_{s}\left(T_{s}\right)+v_{s}\left(P_{s}\right) \leq f,
$$

under the floating exchange rate regime. If the government devalues, it incurs the cost $\mathrm{d}$, whether it repudiates its debts subsequently or not. These inequalities impose upper bounds on $T_{s}$ that are state-contingent and increasing with the state of nature under the fixed rate. Under a float, the bound is also increasing when the government's first-order condition for taxes and seignorage is satisfied, $w_{s}{ }^{\prime}\left(T_{s}\right)=\frac{v_{s}^{\prime}\left(P_{s}\right)}{\sigma_{s}{ }^{\prime}\left(P_{s}\right)}$.

If the outstanding debt is sufficiently large, actual debt repayments will be state contingent under sovereign risk. For example, under a revocable fixed exchange rate, the gross yield on debt would be state contingent and given by

(a19) $T_{s}=\left(1+r_{s}\right) D$

where $w_{s}\left(T_{s}\right)=f$ and the level of debt satisfies

$$
(1+r) D=\sum_{s=1}^{N} \phi_{s}\left(1+r_{s}\right) D=\sum_{s=1}^{N} \phi_{s} T_{s} .
$$

Under the float, the constraint

$$
T_{s}+\sigma_{s}\left(P_{s}\right)=\left(1+r_{s}\right) D\left((1-x)+x \frac{1}{P_{s} E(1 / P)}\right)
$$

holds for $w_{s}\left(T_{s}\right)+v_{s}\left(P_{s}\right)=f$ and $w_{s}{ }^{\prime}\left(T_{s}\right)=\frac{v_{s}^{\prime}\left(P_{s}\right)}{\sigma_{s}{ }^{\prime}\left(P_{s}\right)}$.

Condition (a21) is written for the case that foreign currency and domestic currency debt payments are renegotiated in proportion to face value. In the case that repayments to domestic currency debt are unilaterally reduced with no default on foreign currency debt, post-devaluation inflation is lower and the repayment constraint for state $\mathrm{s}$ is given by

$$
T_{s}+\sigma_{s}\left(P_{s}\right)=(1+r) D(1-x)+\frac{\left(1+r_{s}\right) x D}{P_{s} E(1 / P)} .
$$

The possibility that only foreign debt is renegotiated (realizes state-contingent yields) is analogous.

The presence of sovereign risk will change the effects of debt swaps if the sovereignty immunity constraints are binding in at least some states of nature. Consider a case in which the sovereign immunity constraints are binding in states such that the government abandons the peg (for simplicity, we will let this be all such states), so that $w_{s}\left(T_{s}\right)+v_{s}\left(P_{s}\right)=f$ and $w_{s}{ }^{\prime}\left(T_{s}\right)=\frac{v_{s}{ }^{\prime}\left(P_{s}\right)}{\sigma_{s}{ }^{\prime}\left(P_{s}\right)}$ for each of these states. A swap of domestic currency debt for foreign currency debt will not lead to an increase in $P_{s}$ for each of these states, but, instead, equation (a21) implies that less debt will be repaid in renegotiation. That is, $r_{s}$ must fall because the term, $\left((1-x)+x \frac{1}{P_{s} E(1 / P)}\right)$, rises as $T_{s}+\sigma_{s}\left(P_{s}\right)$ remains constant. For states $\mathrm{s}=\mathrm{j}+1, \ldots, \mathrm{N}$, the swap reduces payments to creditors, $\left(1+r_{s}\right) D\left((1-x)+x \frac{1}{E(1 / P)}\right)$, for any given $r_{s}$. However, the constraints for these states include 
(a23) $T_{s}+\sigma_{s}(1) \geq\left(1+r_{s}\right) D\left((1-x)+\frac{x}{P_{s} E(1 / P)}\right)$,

which implies that $r_{s}$, for $\mathrm{s}=\mathrm{j}+1, \ldots, \mathrm{N}$, can increase without violating the sovereign immunity constraints so that the foreign currency value of debt repayments is unchanged in any state of nature. The debt swap has no effect on the real value of repayments in this case and provides no benefits.

It does not matter if the sovereign immunity constraint is binding or not for any state, $\mathrm{s}=$ $\mathrm{j}+1, \ldots, \mathrm{N}$ for this conclusion to hold. If, however, the constraint does not bind for some state $\mathrm{s}=$ $1, \ldots, \mathrm{j}$, then the debt swap leads to an increase in the price level, $P_{s}$, in this state. The result parallels the case of a debt swap without the possibility of sovereign default (since the default constraint does not bind). A swap then leads to a rise in the shadow exchange rate and tightens the sovereign immunity constraint so that it might bind after the swap. An alternative assumption is that it is costly for the government to renegotiate its debt and that these costs are rising in the amount of debt repayment reduction achieved. In this case, a debt swap will lead to an increase in both $T_{s}$ and $P_{s}$ in states for which the government depreciates. 


\section{References}

Bulow, Jeremy L. and Kenneth Rogoff. 1988. "The buyback boondoggle," Brookings Papers on Economic Activity 2: 675-98.

Chopra, Ajai, Kenneth Kang, Meral Karasulu, Hong Liang, Henry Ma and Anthony Richards.

"From Crisis to Recovery in Korea: Strategy, Achievements and Lessons." Asia and Pacific Department, IMF.

de la Torre, Augusto, and Sergio Schmukler. 2002. “Argentina's Financial Crisis: Floating Money, Sinking Banking," draft, The World Bank.

Flood, Robert, and Peter Garber. 1984. "Collapsing Exchange Rate Regimes: Some Linear Examples.” Journal of International Economics, Vol. 17, pp. 1-13.

Kharas, Homi J., Pinto, Brian, and Ulatov, Sergei. 2001. “An Analysis of Russia's 1998 Meltdown: Fundamentals and Market Signals," Brookings Papers on Economic Activity, 2001, Issue 1.

Kim, Woochan and Yangho Byeon. 2001. "Restructuring Korean Banks' Short-Term Debts in 1998." Draft.

Kletzer, Kenneth Miles, Jr.; Wright, Brian D. 2000. “Sovereign debt as intertemporal barter." American economic review, v.90:3, June, pp. 621-639.

Krugman, Paul. 1979. "A Model of Balance-of-Payments Crises." Journal of Money, Credit and Banking, vol. 11, pp. 311-325.

Mussa, Michael. 2002. “Argentina and the Fund: From Triumph to Tragedy,” Institute for International Economics, Washington DC.

Obstfeld, Maurice, "Models of Currency Crises with Self-Fulfilling Features", European Economic Review, April 1996, p. 1037-47.

Perry, Guillermo, and Luis Serven. 2002. "The Anatomy of a Multiple Crisis: Why was Argentina Special and What Can We Learn From It," The World Bank.

Sargent, Thomas J., and Neil Wallace. 1981. "Some Unpleasant Monetaristic Arithmetic." Federal Reserve Bank of Minneapolis Quarterly Review, Fall 1981, 1-17. 


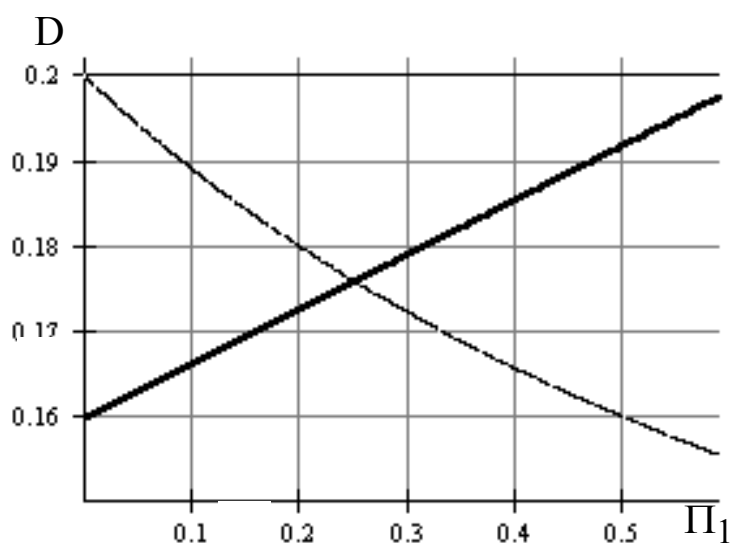

Panel a, $\mathrm{x}=1$

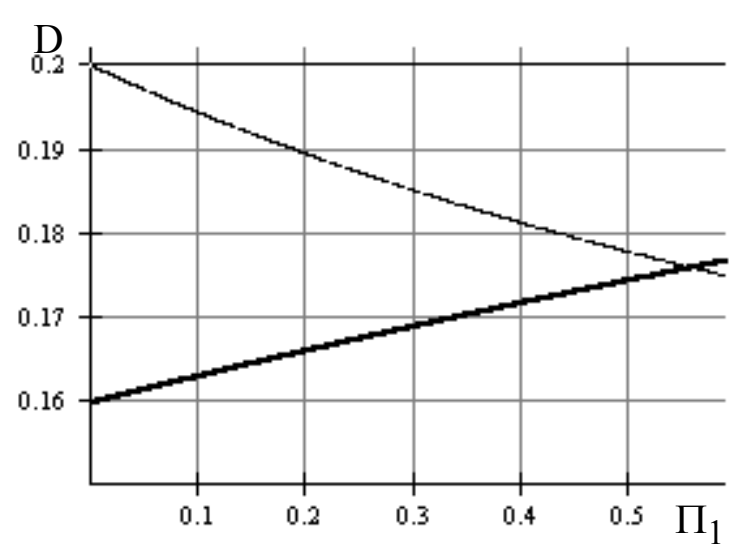

Panel $b, x=0.5$

\section{Figure 1}

Exogenous seignorage, inflation in state $\mathrm{s}=1$ and total debt, for a give share of domestic currency debt $(\mathrm{x})$.

The simulation corresponds to the case of $\mathrm{N}=2, \mathrm{j}=1, \mathrm{~T}_{2}=0.2, \mathrm{~T}_{1}=0.16, \mathrm{r}=0, \phi_{1}=0.6$. 


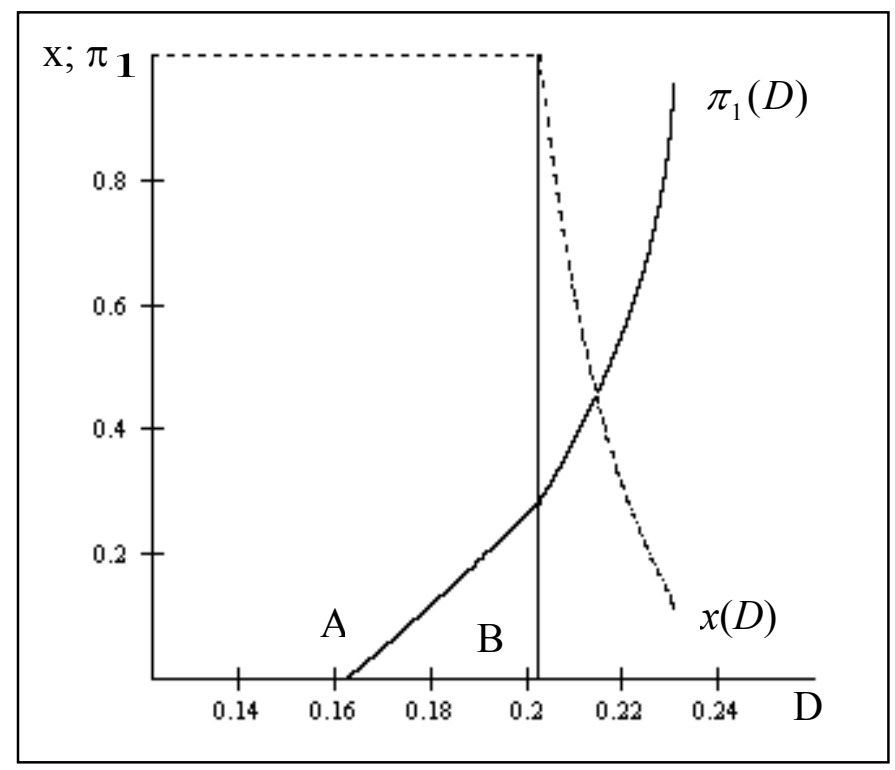

Figure 2

The association between inflation in state $\mathrm{s}=1 \&$ the share of domestic currency debt $(\mathrm{x})$ with aggregate debt, D.

The simulation corresponds to the case of $\mathrm{N}=2, \mathrm{j}=1, \mathrm{~b}=1, \mathrm{k}=0.2, \mathrm{~T}_{2}=0.25, \mathrm{r}=0, \quad \varepsilon=0.35$, $\phi_{1}=0.85$. 


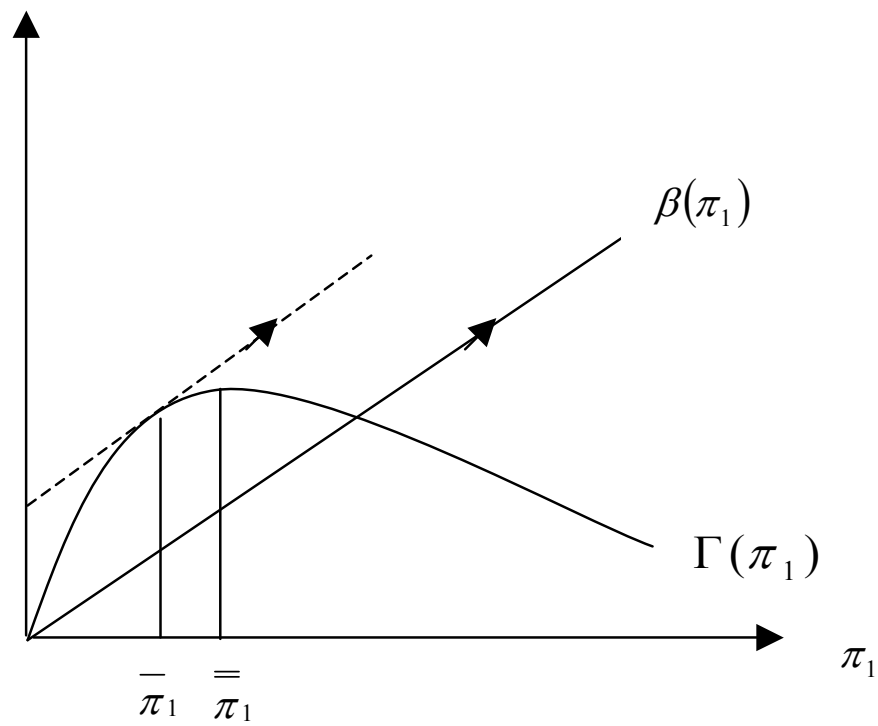

Figure 3

Balance sheet surprises and swaps 